\title{
In Vivo Lability of Red Cell Phosphofructokinase in Term Infants: The Possible Molecular Basis of the Relative Phosphofructokinase Deficiency in Neonatal Red Cells
}

\author{
SUSAN F. TRAVIS, (19) AND JAMES H. GARVIN, JR. \\ Department of Pediatrics and Cardeza Foundation for Hematologic Research, Thomas Jefferson University School \\ of Medicine, Philadelphia, Pennsylvania, USA
}

\begin{abstract}
Summary
Cord blood erythrocytes from nine term infants were separated by density gradient centrifugation into cohorts of intact cells of progressively increasing density and compared with red cells treated in a similar manner from four healthy adults. Pyruvate kinase $(\mathrm{PK})$, an age-dependent enzyme, progressively decreased in activity from the lightest to the heaviest fractions, in both neonatal and adult red cells, indicating that red cells from newborn infants exhibit the same relationship between red cell age and density that had previously been demonstrated in red cells from adults. The rate of decline of red cell PK activity was essentially the same in neonates and adults, whereas phosphofructokinase (PFK) activity in cord erythrocytes decreased at a pignificantly faster rate when compared to adults. These data suggest that PFK has an accelerated rate of in vivo decay in neonatal red cells and is an unstable enzyme in the newborn.
\end{abstract}

\section{Speculation}

The finding that PFK from cord blood has an accelerated rate of in vivo decay suggests that the relative PFK deficiency that exists in neonatal red cells is secondary to normal synthesis of an unstable enzyme, and leads to the speculation that red cell PFK in newborn infants is an isozyme (a "fetal" PFK).

Erythrocytes of newborn infants are known to differ considerably from those of adults. They have a decreased lifespan (2) and uppear to consume less glucose than cells of a similar young mean cell age (11). The activities of the glycolytic enzymes enolase and phosphoglycerate kinase (PGK) are disproportionitely elevated $(6,10,17)$, whereas PFK activity is significantly educed $(3,7,10)$.

Recently, investigations of PFK activity in "young" and "old" rythrocytes from cord blood (light and heavy cells, respectively) have demonstrated normal enzyme levels in the young fraction ind decreased activity in the old fraction when compared to idults (9). On the basis of these studies it was proposed that red ells produced early in fetal life are more deficient in PFK than ed cells produced just before term. Alternatively, the data could be consistent with a normal rate of synthesis of a more abile (an unstable) enzyme.

The present studies were designed to test the latter hypothesis ff increased enzyme lability. Erythrocytes from cord blood can e specifically and reproducibly separated into groups of intact rythrocytes of increasing density by using the technique of Iltracentrifugation on a discontinuous density gradient $(5,13$, 4). Utilizing this technique, the relationship between red cell ige and density has been demonstrated previously in adult red ells, and has permitted quantitative estimation of the rate of decline of red cell enzymatic activity in vivo by measuring the serial decline in activity of red cells of progressively increasing mean cell age (density) $(5,12-14)$. Pyruvate kinase, an agedependent enzyme, was found to have a marked rate of decline with a half-life $\left(t_{1}\right)$ of approximately $30-33$ days $(12,13)$. This property permits $\mathrm{PK}$ activity to be used as a parameter of agerelated fractionation in the gradient (13). Although these studies have been performed in red cells from adults, it seems reasonable to assume that, in a similar manner, the in vivo rate of decline of PFK activity with aging of the erythrocyte can be compared in red cells from cord blood and normal adults and contrasted with the rate of in vivo decline of PK. This comparison would be valid only if the rate of decline of PK is essentially the same in neonatal and adult red cells, and a similar relationship between red cell age and density exists in neonatal red cells.

\section{MATERIALS AND METHODS}

Fresh blood from healthy term infants and adult laboratory personnel was collected in tubes containing dried sodium heparin (Vacutainer, Becton-Dickinson and Co., Rutherford, N. J.). The infant blood was obtained from the placenta immediately after clamping of the umbilical cord. After centrifugation at 400 rpm in a PR-J (International Equipment Company, Needham Heights, Mass.) centrifuge at $4^{\circ}$, for $10 \mathrm{~min}$, the white cell and platelet-rich plasma were removed. The cells were then diluted in at least 5 parts cold buffered saline with glucose (buffered with $\mathrm{PO}_{4}$ to $\mathrm{pH} 7.4$, containing $200 \mathrm{mg} / 100 \mathrm{ml}$ glucose) and filtered three times through double layers of Whatman no. 2 filter paper. After each filtration, the resuspended cells were recentrifuged, and the process was then repeated. Cells prepared in this manner are essentially white cell free.

Separation of erythrocytes by density was achieved by density gradient centrifugation according to published procedures (5, 14). The packed red cells $(0.5-0.75 \mathrm{ml})$ were layered onto gradients comprising discontinuous $2-\mathrm{ml}$ layers of an arabinogalactan polysaccharide solution, Stractan II (kindly supplied by St. Regis Paper Co., Tacoma, Wash.) and upon centrifugation in a Beckman (Beckman Instruments, Inc., Broomall, Pa.) ultracentrifuge with a swinging bucket rotor (up to $52,000 \times g$ for 60 $\min$ at $4^{\circ}$ ) they tended to migrate to the interfaces between layers. For separation of neonatal erythrocytes, layers of density $=1.075,1.080,1.085,1.090$, and 1.095 were chosen, whereas the corresponding layers for adult cells had density $=1.083$, $1.087,1.091,1.095$, and 1.099 . After centrifugation the tubes were cut with a tube slicer (Beckman Instruments, Inc.) to isolate the bands of erythrocytes. Each band was diluted in $10 \mathrm{ml}$ phosphate-buffered saline with glucose and the $O D_{5+4}$ was determined as a measure of the proportion of cells present in each fraction. 
Table 1. Phosphofructokinase activity of neonatal and adult red cells separated on discontinuous density gradients ${ }^{1}$

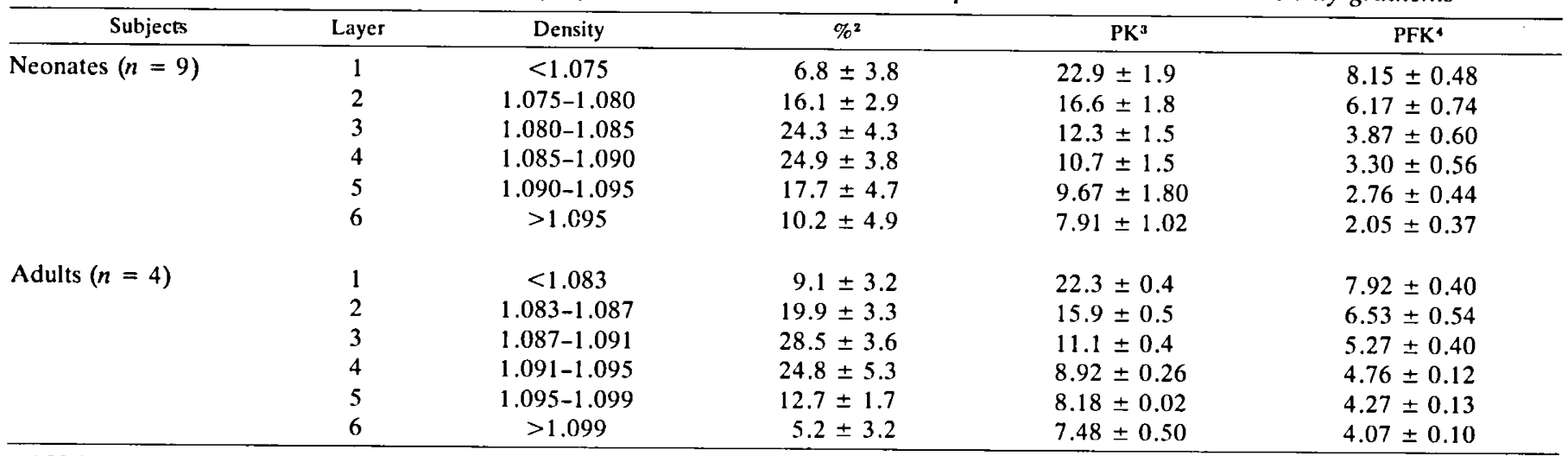

1 Values are expressed as the mean \pm SD. PK: pyruvate kinase; PFK: phosphofructokinase.

$2 \%$ cells present in each layer.

${ }^{3}$ Pyruvate kinase, units per $\mathrm{g}$ hemoglobin.

${ }^{4}$ Phosphofructokinase, units per g hemoglobin.

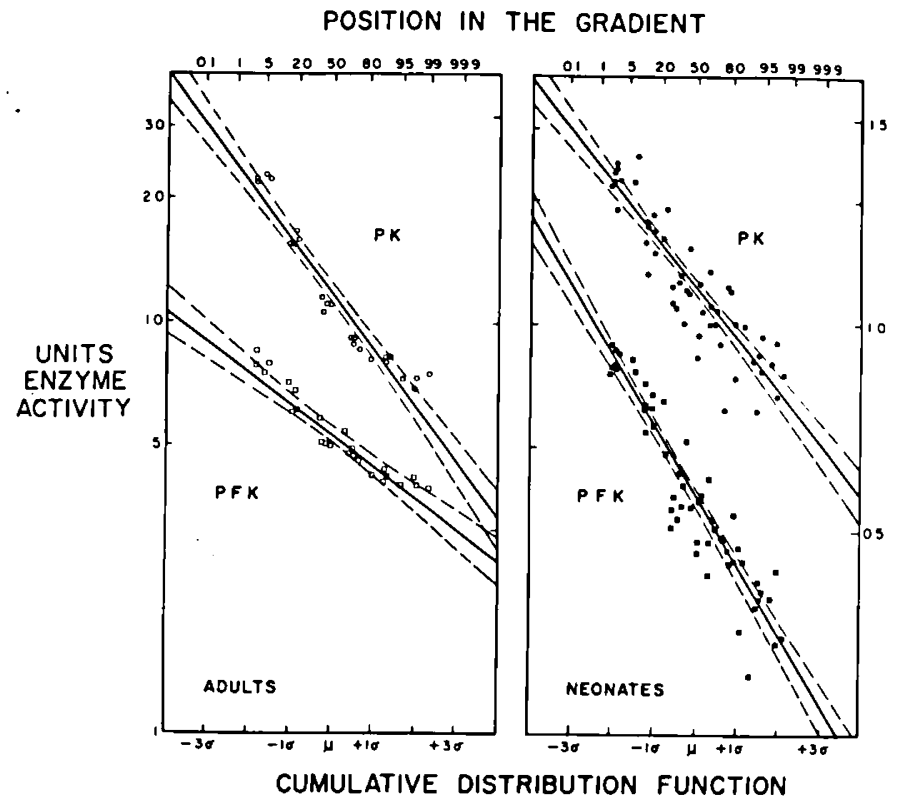

Fig. 1. Rates of decline of pyruvate kinase $(P K)$ and phosphofructokinase $(P F K)$ in adult and neonatal red cells in a discontinuous density gradient. Units of enzyme activity expressed as international units per $\mathrm{g}$ Hb. Horizontal axis: probability scale; vertical axis: logarithmic scale. -: slopes of regression; ---: $95 \%$ confidence limits of the slopes.

Hemolysates were then prepared from each erythrocyte aliquot (washed free of glucose with buffered saline) in order to assay PFK (4) and PK (13) activities, expressed in terms of grams of hemoglobin (1). For the PFK assay, erythrocytes were lysed in $2 \mathrm{mM}$ EDTA-0.05\% 2-mercaptoethanol (ph 7.4) and freeze-thawed, whereas for the PK assay $5 \mathrm{mM}$ TES ( $n$-trishydroxymethyl) methyl-2-aminoethane sulfonic acid) buffer, $\mathrm{pH}$ 7.4 , containing $1 \mathrm{mM}$ EDTA and $1 \mathrm{mM}$ mercaptoethanol was used. All enzyme assays were performed at $25^{\circ}$ and $340 \mathrm{~nm}$ using a Gilford model 2000 recording spectrophotometer. Statistical analysis of the data was performed according to published procedures (13).

In these studies, the lifespan of PK from red cells from adults was estimated, as described by Piomelli et al. (13), and was found to have a $t_{t}$ of 34 days. This value is essentially the same as that previously reported (13) in control subjects (33 days). Since the same authors have documented and reported the agerelated fractionation of both glucose-6-phosphate dehydrogen-

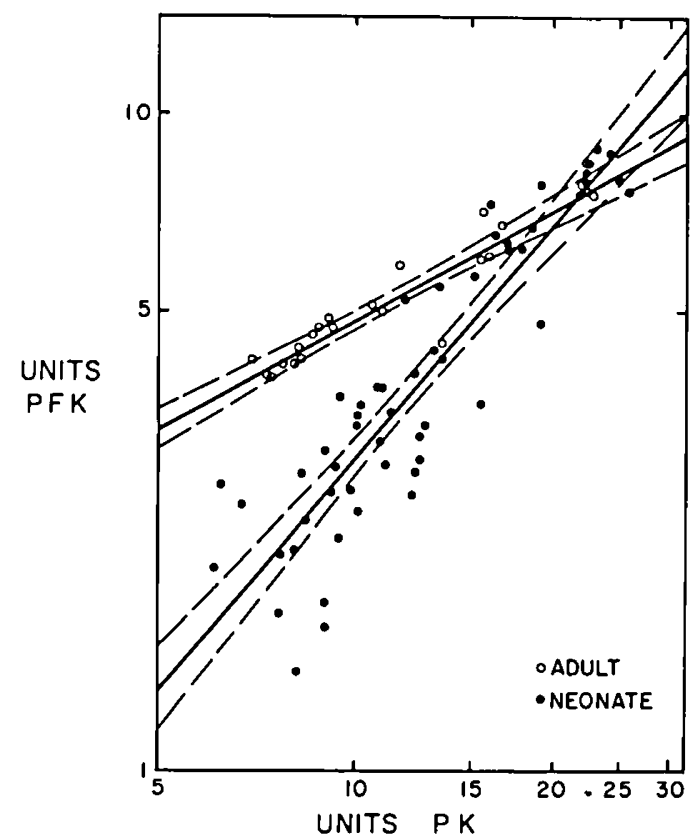

Fig. 2. Activity of phosphofructokinase $(P F K)$ in adult and neonatal red cells vs. pyruvate kinase $(P K)$ activity. Units of enzyme activity: units per $\mathrm{g} \mathrm{Hb}$. Horizontal and vertical axes: Logarithmic scale.

ase and reticulocytes in both albumin (13) and in the same gradient system (5) used in this laboratory (Stractan II), it was considered unnecessary to repeat these studies since the $t_{1}$ of PK was essentially the same in both laboratories.

\section{RESULTS}

\section{PATTERN OF FRACTIONATION}

The age of the erythrocyte distributions obtained in the density gradients was indirectly demonstrated by measuring the activity of PK, a markedly age-dependent enzyme. The younger cells typically migrated at lower densities and a serial decline in PK activity was seen from the lightest to the heaviest layers (Table 1).

It should be noted that when the density gradients were prepared, a lower specific gravity was used for each corresponding layer of neonatal red cells when compared to adults in order to compensate for the lighter density of the red cell population known to exist in the newborn. In this manner, comparably sized cohorts of red cells with similar PK activity were obtained in 
each layer, which permitted direct comparisons between individual "age-matched" fractions.

PFK activity in the two youngest fractions of neonatal red cells was not significantly different from that of corresponding agematched fractions of adult cells (Table 1). When older fractions were compared, there was a $75 \%$ loss of PFK activity between the youngest and oldest fractions of neonatal red cells, and only the youngest one-third of cells retained at least half of the maximal PFK activity. In the adult red cells, there was only a $49 \%$ decline in PFK overall, so that even the oldest cells retained more than half the original PFK activity.

\section{RATE OF DECLINE OF PK}

The rate of decline of $\mathrm{PK}$ in adult and neonatal erythrocytes in the gradient was essentially the same (Fig. 1). This suggests that the rate of decline in PK activity bears the same relationship to the increase in gravity (density) that accompanies aging of the red cell in newborns as it does in adults.

\section{RATE OF DECLINE OF PFK}

The rate of decline of $P F K$ in neonatal erythrocytes was significantly faster than in adult red cells (Fig. 1), suggesting an accelerated rate of in vivo decay. This is more clearly demonstrated when the log of the activity of PFK in neonatal and adult red cells is plotted against the log of the PK activity (Fig. 2), since both enzymes decline exponentially with red cell age.

\section{DISCUSSION}

The existence of a relative deficiency of PFK in erythrocytes from normal newborn infants could result theoretically from lower catalytic efficiency, decreased synthesis or increased lability of the neonatal enzyme, or combined mechanisms. Our studies have confirmed the previously reported finding that maximal PFK activity is similar in the youngest fractions of cord and adult erythrocytes (9), which suggests that the neonate is capable of synthesizing a normal amount of enzyme. However, PFK activity is markedly diminished in the "oldest" fraction of cord erythrocytes. On the basis of this finding it has been suggested that cells produced early in fetal life are more deficient in PFK (9). However, results obtained in our laboratory (16) and elsewhere (3) suggest that the relative deficiency of PFK persists in developing infants beyond the usual lifespan of cord erythrocytes.

Our studies have allowed serial measurement of PFK and PK activity in groups of intact erythrocytes of progressively increasing density. The rate of decline of PK, an age-dependent enzyme, was essentially the same in erythrocytes from term infants and adults. This demonstrated that there is a relationship in newborn red cells between the rate of decline of PK activity and the progressive increase in red cell density that occurs with aging similar to that which had previously been confirmed in adult red cells $(5,12,13)$. Thus, it appears that $P K$ is a useful parameter of red cell age in the gradient in the newborn as well as in the adult, and that the layers of progressively increasing density in the gradient most probably reflect layers of progressively increasing mean red cell age, as in the adult. This relationship permitted evaluation of the rate of decline of in vivo enzymatic activity. In contrast to the similar rate of decline of $P K$ in red cells from infants and adults, the rate of decline of PFK was much faster in neonates than in adults. The results demonstrated that PFK in cord erythrocytes has increased lability in the gradient and suggest that the relative PFK deficiency in neonates is secondary to normal synthesis of an unstable enzyme.

The finding that PFK in cord blood may be an unstable enzyme, combined with the recent demonstration that PFK appears to be less sensitive to $\mathrm{pH}$ activation in cord erythrocytes than in red cells from adults (9), raises the speculation that PFK in cord blood may be an isozyme (a "fetal PFK"). This concept is further supported by preliminary results obtained in this laboratory which demonstrated that the rise in PFK activity toward normal adult values in infants during the first year of life, correlates inversely with the postnatal decline in fetal hemoglobin (15). Furthermore, Kahn et al. (8) have reported that PFK from premature infants and "old" red cells from term infants were less neutralized by anti-muscle PFK serum than PFK from adult red cells, suggesting that fetal erythrocytes were relatively deficient in the muscle-type subunit of erythrocyte PFK. Further characterization of PFK from cord erythrocytes awaits investigation as does the functional significance of the relative PFK deficiency in neonatal red cells.

\section{ADDENDUM}

Since this paper was submitted for publication, Vora and Piomelli (Pediat. Res., 11: 483 (1977), Abstract) have demonstrated that PFK purified in DEAE-Sephadex columns at $\mathrm{pH} 8.0$ has one peak that elutes between muscle and liver PFK in adult red cells, but that PFK from cord blood elutes as two peaks, one identical to the adult and one that appears to be the same PFK from liver. These results are highly suggestive of the existence of a "fetal" PFK isozyme in the newborn.

\section{REFERENCES AND NOTES}

1. Beutler, E.: Red Cell Metabolism: A Manual of Biochemical Methods, p. 13 (Grune \& Stratton, New York, 1971).

2. Bratteby, L. E., Garby, L., Groth, T., et al.: Studies on erythrokinetics in infancy. XIII. The mean life span and the life span frequency function of red blood cells formed during fetal life. Acta Paediat. Scand, ,57: 311 (1968).

3. Caruso, P.. Conti, F., and Londrillo, A.: Diagramma delle attività enzimatiche endoeritrocitarie nel neonato, nel lattante, nel bambino. Minerva Pediat., 15: 1136 (1963).

4. Chapman, R. G., Hennessey, M. A., Waltersdorph, A. M., et al.: Erythrocyte metabolism. V. Levels of glycolytic enzymes and regulation of glycolysis. $J$. Clin. Invest., 41: 1249 (1962)

5. Corash, L. M., Piomelli, S., Chen, H. C., et al.: Separation of erythrocytes according to age on a simplified density gradient. J. Lab. Clin. Med., 84: 147 (1974).

6. Cotte, J., Nivelon, L., Cuivré, M., et al.: Les enzymes de la glycolyse intraérythrocytaire chez le prématuré. Ann. Pédiat., 43: 3158 (1967).

7. Gross, R. T., Schroeder, E. A. R., and Brounstein, S. A.: Energy metabolism in the erythrocytes of premature infants compared to full term newborn infants and adults. Blood, 21: 755 (1963).

8. Kahn, A., Cottreau, D., Boyer, C., et al.: Causal mechanisms of multiple acquired red cell enzyme defects in a patient with acquired dyserythropoiesis. Blood, 48: 653 (1976).

9. Komazawa, M., and Oski, F. A.: Biochemical characteristics of "young" and "old" erythrocytes of the newborn infant. J. Pediat., 87: 102 (1975).

10. Oski, F. A.: Red cell metabolism in the newborn infant. V. Glycolytic intermediates and glycolytic enzymes. Pediatrics, 44: 84 (1969).

11. Oski, F. A., and Smith, C.: Red cell metabolism in the premature infant. III. Apparent inappropriate glucose consumption for cell age. Pediatrics, 41: 473 (1968).

12. Piomelli, S., and Corash, L.: Hereditary hemolytic anemia due to enzyme defects of glycolysis. In: H. Harris and K. Hirschhorn: Advances in Human Genetics, Vol. 6, p. 165 (Plenum Press, New York, 1976).

13. Piomelli, S., Corash, L. M., Davenport, D. D., et al.: In vivo lability of glucose-6-phosphate dehydrogenase in $\mathrm{Gd}^{\mathrm{A}-}$ and $\mathrm{Gd}^{\text {Mediterranean }}$ deficiency. J. Clin. Invest., 47: 940 (1968).

14. Piomelli, S., Lurinsky, G., and Wasserman, L. R.: The mo shanism of red cell aging. I. Relationship between cell age and specific gra $/$ ity evaluated by ultracentrifugation in a discontinuous density gradient. J. Lab. Clin. Med., 69: 659 (1967).

15. Travis, S. F., Patel, B., Cannon, E., et al.: Control mechanisms influencing the metabolic characteristics of erythrocytes from normal term infants during the first year of life. Pediat. Res., 10: 383 (1976).

16. Travis, S. F., Solow, J. M., Patel, B., et al.: Developmental changes of red cell glycolytic enzymes and intermediates in normal term infants during the first year of life. Pediat. Res., 9: 327 (1975).

17. Witt, I., Müller, H., and Künzer, W.: Vergleichende biochemische Untersuchungen an Erythrocyten aus Neugeborenen und Erwachsenen-Blut. Klin., Wschr., 45: 262 (1967).

18. The authors would like to express their appreciation to Mrs. Carol Seaman, for her suggestions and help in the statistical analysis of the data.

19. Requests for reprints should be addressed to: S. F. Travis, M.D., Thomas Jefferson University School of Medicine, Cardeza Foundation for Hematologic Research, 1015 Walnut St., Philadelphia, Pa. 19107.

20. Received for publication January $4,1977$.

21. Accepted for publication March 28, 1977 